\title{
DESKRIPSI PENGETAHUAN DAN PENERAPAN TANAMAN OBAT KELUARGA (TOGA) DI DESA PINILIH KECAMATAN DIMEMBE KABUPATEN MINAHASA UTARA
}

\author{
Cristian Hendri Mewengkang \\ Elsje Pauline Manginsela \\ Melsje Yellie Memah
}

\begin{tabular}{ll}
\hline Naskah diterima melalui Website Jurnal Ilmiah agrisosioekonomi@unsrat.ac.id & : Kamis, 09 Januari 2020 \\
Disetujui diterbitkan & : Sabtu, 11 Januari 2020 \\
\hline
\end{tabular}

\begin{abstract}
This study aims to describe the knowledge and application of this knowledge about the types of Family Medicinal Plants (TOGA). Research location in Pinilih Village, Dimembe Sub-district, North Minahasa Regency. The data used in this study are primary and secondary data. The sample selection is done intentionally, namely the community members who plant medicinal plants in their homeyard. Primary data collection conducted by direct interviews with 20 community members with the help of a list of questions. Secondary data were obtained from the Pinilih Village Office, University Library, and the Internet. The method of analysis used in this research is descriptive analysis. The results showed that respondents had knowledge of the types of medicinal plants and knew their benefits. There were those who know the uses of medicinal plants without using or applying them and there were also not only knowing but also applying their knowledge. Knowledge about types of medicinal plants and their benefits and how to use them is applied in family life because it is a legacy from the family therefore that has been used for a long time and is still used until today. The types of medicinal plants of this family are not only planted in the yard but also in the garden. ${ }^{* e p r m *}$
\end{abstract}

Keywords: knowledge, use, application, medicinal plants, family medicinal plants, Pinilih Village

\begin{abstract}
ABSTRAK
Penelitian ini bertujuan untuk mendeskripsikan pengetahuan dan penerapan pengetahuan tersebut tentang jenis-jenis Tanaman Obat Keluarga (TOGA). Lokasi penelitian di Desa Pinilih Kecamatan Dimembe Kabupaten Minahasa Utara. Data yang digunakan dalam penelitian ini adalah data primer dan sekunder. Pemilihan sampel dilakukan secara sengaja yaitu pada anggota masyarakat yang menanam tanaman obat di pekarangan rumahnya. Pengumpulan data primer berupa wawancara langsung pada 20 anggota masyarakat dengan bantuan daftar pertanyaan. Data sekunder diperoleh dari Kantor Desa Pinilih, perpustakaan, dan Internet. MetodeAnalisis yang digunakan dalam penelitian ini yaitu dengan menggunakan analisis deskriptif. Hasil penelitian menunjukkan bahwa responden memiliki pengetahuan jenis-jenis tanaman obat dan mengetahui manfaatnya. Ada yang mengetahui kegunaan tanaman obat saja tanpa menggunakan atau menerapkannya ada juga tidak hanya mengetahui tetapi juga menerapkan pengetahuannya. Pengetahuan tentang jenis tanaman obat dan manfaatnya maupun cara penggunaannya diterapkan dalam kehidupan keluarga karena merupakan warisan dari keluarga yang sudah digunakan sejak lama dan masih digunakan sampai sekarang. Jenis-

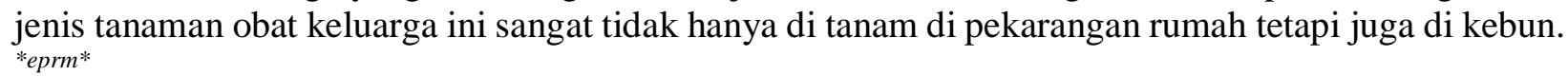

Kata kunci: pengetahuan, kegunaan, penerapan, tanaman obat, tanaman obat keluarga, Desa Pinilih 


\section{PENDAHULUAN}

Indonesia banyak memiliki jenis tanaman obat yang tersebar di berbagai daerah, sehingga dikenal sebagai gudangnya tanaman obat dan mendapatkan julukan life laboratory. Keuntungan penggunaa obat tradisonal yang dirasakan langsung oleh masyarakat adalah kemudahan untuk memperolehnya dan bahan bakunya dapat ditanam di pekarangan sendiri, murah dan dapat diramu sendiri dirumah (Zein, 2005).

Saat ini terjadi peningkatan kesadaran masyarakat akan pentingnya kesehatan, menjadikan kebutuhan akan pelayanan kesehatan makin meningkat. Berbagai upaya yang dilakukan oleh Kantor Kementerian Kesehatan dalam hal pemerataan kesehatan, namun masih ada kelompok masyarakat yang belum terjangkau terutama masyarakat di pelosok daerah dan masyarakat yang tingkat ekonominya masih rendah. Kondisi keterisolasian dan pendapatan yang masih rendah merupakan peyebab utama bagi mereka untuk mendapatkan pelayanan kesehatan yang memadai tidak dapat terpenuhi. Sebagai alternatif maka peranan pengetahuan pengobatan dengan memanfaatkan tanaman obat sangat penting (Rosita, dkk. 1993).

Kata kesehatan menggambarkan keadaan sejahtera dari badan, jiwa, dan sosial yang menunjukkan setiap orang hidup produktif secara sosial, dan ekonomis (Nurhidayat, 2012), yang diarahkan pada kegiatan meningkatkan, mempertahankan, dan memulihkan status kesehatan untuk mencegah penyakit (Riyanto, 2016). Setiap masalah kesehatan baik penyakit ringan maupun berat mampu diobati dengan ramuan dari obat-obatan tumbuhan tertentu yang didapat disekitar pekarangan rumah atau dikebun dengan hasil yang cukup memuaskan. Dan pengobatan menggunakan obat tradisional mempunyai keistimewaan atau kelebihan sendiri dimana tidak ada efek samping karena berbahan alami dari alam dibandingkan dengan obat kimia.

Penggunaaan bahan alam sebagai obat tradisional telah dilakukan oleh nenek moyang kita sejak berabad-abad yang lalu. Terbukti dari adanya naskah lama pada daun lontar Husodo (Jawa), Usada (Bali), Lontarak Pabbura (Sulawesi Selatan), dokumen serat primbon Jambi, serat racikan Boreh Wulang Dalem dan relief candi Borobudur yang menggambarkan orang yang sedang meracik obat (Jamu) dengan tumbuhan sebagai bahan bakunya (Sukandar, 2006 dalam Sari, 2012).
Salah satu cara untuk dapat tetap menjaga dan mengontrol kesehatan yaitu dengan ketersediaan dan mengkonsumsi tanaman obat. Obat tradisioanal merupakan warisan budaya bangsa sehingga perlu dilestarikan (Dewoto, 2007). Tanaman obat tradisional mempunyai peranan penting dalam dunia kesehatan yang pemakainya sudah lama dikenal dan digunakan masyarakat Indonesia. Penggunaan obat tradisional; akhir-akhir ini mengalami peningkatan, hal ini dipengaruhi oleh kenaikan harga-harga obat-obat modern di masa krisis ekonomi (Supriyadi, 2001). Namun belum banyak species tanaman obat yang dimanfaatkan dan diteliti sebagai obat tradisional. Tanaman obat yang akan dibahas yaitu tanaman obat dalam lingkup keluarga, atau yang biasa dikenal dengan sebutan tanaman obat keluarga (TOGA).

Pada masyarakat tradisional dikenal dengan adanya tenaga kesehatan tradisional yang antara lain disebut dukun atau orang pintar yang mempunyai pengetahuan dan keahlian dalam meracik atau meramu tumbuhan sehingga dapat berkhasiat obat. Namun pengetahuan yang ada pada masyarakat tradisional tentang tumbuhan obat tersebut jarang dituangkan dalam bentuk tulisan. Kebanyakan hanya dipahami oleh para orangtua atau generasi sebelumnya, sehingga generasi masyarakat saat ini jarang peduli, mengetahui ataupun menggunakan. Sehingga pengetahuan dan disertakan dengan penerapan akan manfaat tanaman obat ini perlu terusmenerus disosialisasikan agar tidak hilang ditelan modernisasi budaya.

Desa Pinilih merupakan salah satu desa yang ada di Kecamatan Dimembe. Penduduk desa ini terdistribusi di empat (4) jaga (dusun) dengan jarak ke pusat-pusat pemerintahan di antaranya: jarak kepusat pemerintahan kecamatan $15 \mathrm{~km}$, jarak ke pusat pemerintahan kabupaten sejauh $22 \mathrm{~km}$, jarak ke pusat pemerintahan provinsi sejauh $35 \mathrm{~km}$. luas wilayah Desa Pinilih sekitar $950 \mathrm{Ha}$. Penggunaan lahan untuk wilayah pemukiman sebesar $19 \mathrm{Ha}$, sawah seluas $32 \mathrm{Ha}$, kolam seluas $4 \mathrm{Ha}$, hutan seluas sekitar 500 Ha. Desa Pinilih berbatasan langsung dengan Hutan Mawiau di sebelah Utara, dengan Desa Klabat dan Gunung Klabat di sebelah Selatan, dengan perkebunan Desa Klabat di sebelah Timur, dan dengan Desa Tatelu di sebelah Barat. 
Masyarakat di desa ini juga memanfatkan tumbuhan sebagai obat untuk mengobati berbagai penyakit. pengetahuan tentang pengobatan diturunkan antar generasi. Namun, pengetahuan tentang pengobatan dengan memanfaatkan tumbuhan sebagai obat tidak merata dalam masyarakat. Untuk itu perlu pengumpulan informasi mengenai pengetahuan tentang tanaman obat, selain itu agar pengetahuan dan penerapan tradisional ini tetap terus secara turun temurun disebar luaskan atau diteruskan kepatan generasi penerus, sehingga pengetahuan tradisional ini tidak akan menghilang.

Sehubungan dengan hal tersebut untuk mengetahui pemanfaatan tumbuhan obat oleh masyarakat Pinilih maka diperlukan studi mengenai pengetahuan dan penerapan tumbuhan obat keluarga (TOGA) di Desa Pinilih, Kecamatan Dimembe.

\section{Perumusan Masalah}

Berdasarkan latar belakang yang telah dikemukakan maka perumusan masalah dalam penelitian ini adalah bagaimana pengetahuan masyarakat tentang tanaman obat keluarga serta penerapannya di Desa Pinilih.

\section{Tujuan Penelitian}

Tujuan penelitian adalah untuk mendeskripsikan baik pengetahuan maupun penerapan pengetahuan tersebut tentang tanaman obat keluarga pada masyarakat di Desa Pinilih.

\section{Manfaat Penulisan}

Manfaat dari penulisan ini adalah untuk meningkatkan pengetahuan dan penerapan tanaman obat keluarga. Penulisan ini juga diharapkan dapat menjadi bahan studi referensi untuk penulis-penulis selanjutnya dan referensi dalam melaksanakan suatu penelitian yang menyangkut pengetahuan dan penerapan dari tanaman obat keluarga.

\section{METODE PENELITIAN}

\section{Waktu dan Tempat Penelitian}

Penelitian ini dilaksanakan selama 5 bulan yaitu dari bulan Februari sampai dengan bulan Juni tahun 2018 dan mengambil lokasi di Desa Pinilih, Kecamatan Dimembe, Minahasa Utara.

\section{Metode Pemilihan Responden}

Pemilihan responden dilakukan secara sengaja (purposive sampling) dengan pertimbangan responden yang terpilih untuk diwawancara adalah responden halamannya ditanami tanaman obat keluarga. Jumlah responden 20 orang yang terdiri atas 10 perempuan dan 10 laki-laki dan semuanya sudah menikah.

\section{Metode Pengumpulan Data}

Pengumpulan data dilakukan dengan wawancara menggunakan kuesioner yang berisi pertanyaan dalam bentuk pertanyaan terbuka.

\section{Konsep Pengukuran Variabel}

Variabel yang akan digunakan pada penelitian ini adalah:

1. Karakteristik:

a) Umur responden, yaitu dilihat dari pengguna tanaman obat yang dinyatakan dalam tahun.

b) Jenis kelamin, yaitu laki-laki dan perempuan $(\mathrm{L} / \mathrm{P})$.

2. Jenis-jenis tanaman obat keluarga

\section{Metode Analisis Data}

Teknik analisis data yang digunakan dalam penelitian ini adalah analisis deskriptif. Analisis deskriptif bertujuan untuk memahami dengan lebih baik atau lebih dalam mengenai setiap permasalahan sosial dan interaksi manusia dan untuk mendapat jawaban yang lebih dalam mengenai suatu fenomena sosial.

Analisis deskriptif berusaha mencari pemecahan masalah dengan menganalisis dari gambaran hubungan sebab akibat dari faktor-faktor tertentu yang berhubungan dengan fenomena dari objek yang akan diteliti.

\section{HASIL DAN PEMBAHASAN}

\section{Deskripsi Wilayah Penelitian}

\section{Sejarah Desa}

Desa Pinilih awal mulanya bernama Patani'in Winetin yang artinya wilayah baru yang dipilih, kemudian berganti nama Girian Atas yang artinya pusat kegiatan neger pada masa itu berada di hulu Sungai Girian, kemudian Girian Atas berganti nama menjadi Pinilih yang artinya "dipilih". Pada tanggal 14 Juli 2014 dilaksanakan seminar tentang sejarah berdirinya Desa Pinilih dan diputuskan bahwa Hari ulang tahun Desa Pinilih ditetapkan pada tanggal 28 Juli 1914. 


\section{Kondisi umum Desa Pinilih}

Desa Pinilih merupakan salah satu desa yang ada di Kecamatan Dimembe. Penduduk desa ini terdistribusi di 4 jaga (dusun) dengan jarak ke pusatpusat pemerintahan di antaranya: jarak kepusat pemerintahan kecamatan $15 \mathrm{~km}$, jarak ke pusat pemerintahan kabupaten sejauh $22 \mathrm{~km}$, jarak ke pusat pemerintahan provinsi sejauh $35 \mathrm{~km}$. Luas wilayah Desa Pinilih sekitar 950 Ha. Penggunaan lahan untuk wilayah pemukiman sebesar $19 \mathrm{Ha}$, sawah seluas 32 $\mathrm{Ha}$, kolam seluas $4 \mathrm{Ha}$, hutan seluas sekitar $500 \mathrm{Ha}$. dengan batas wilayah:
Sebelah Utara
: Hutan Mawiau
Sebelah Timur
: Perkebunan Desa Klabat
Sebelah Selatan
: Desa Klabat dan Gunung
Sebelah Barat
Klabat
: Desa Tatelu

\section{Luas Wilayah}

Luas wilayah Desa Pinilih adalah $950 \mathrm{Ha}$, yang membujur dari arah Timur ke Barat.

\section{Tata Guna Tanah Desa Pinilih}

$\begin{array}{ll}\text { Tanah Pemukiman } & : 19 \mathrm{Ha} \\ \text { Tanah Pertanian (Sawah) : } 32 \mathrm{Ha} & \\ \text { Tanah Ladang } & : 98 \mathrm{Ha} \\ \text { Kolam } & : 4 \mathrm{Ha} \\ \text { Hutan } & : 500 \mathrm{Ha}\end{array}$

\section{Keadaan Sosial}

\section{Jumlah Penduduk}

Jumlah penduduk di Desa Pinilih yang tersebar dalam 4 jaga dengan perincian pada Tabel 2.

\section{Tabel 2. Jumlah Penduduk}

\begin{tabular}{llcr}
\hline No & Jenis kelamin & Jumlah (Jiwa) & Persentase(\%) \\
\hline 1. & Laki-laki & 692 & 52,38 \\
2. & Perempuan & 629 & 47,62 \\
\hline & Jumlah & $\mathbf{1 . 3 2 1}$ & $\mathbf{1 0 0}$ \\
\hline
\end{tabular}

Sumber: Data Statistik Desa Pinilih, 2016

Tabel 2 menunjukkan bahwa penduduk yang berjenis kelamin laki-laki lebih banyak dari pada penduduk perempuan. Jumlah keseluruhan penduduk sebanyak 1.321 jiwa, yang terdiri laki_laki 692 jiwa dengan persentase $52,38 \%$, dan perempuan sebanyak 629 jiwa dengan persentase $47,62 \%$.

\section{Tingkat Pendidikan}

Tabel 3 menunjukkan bahwa kebanyakan penduduk Desa Pinilih, berpendidikan SD dengan jumlah 531 orang dengan persentase $37,93 \%$ dan merupakan jumlah pendidikan tertinggi. Sedangkan tingkat pendidikan akademik berjumlah 6 orang dengan persentase $0,43 \%$ merupakan jumlah terendah. Semakin tinggi pendidikan maka semakin tinggi pula jumlah penduduk yang dapat meraihnya.

\begin{tabular}{|c|c|c|c|}
\hline No & Tingkat pendidikan & Jumlah (orang) & Persentase $(\%)$ \\
\hline 1. & $\begin{array}{l}\text { BELUM/TIDAK } \\
\text { SEKOLAH }\end{array}$ & 176 & 12,57 \\
\hline 2. & TK & 35 & 2,50 \\
\hline 3. & SD & 531 & 37,93 \\
\hline 4. & SLTP & 276 & 19,71 \\
\hline 5. & SLTA & 322 & 23,00 \\
\hline 6. & AKADEMIK & 6 & 0,43 \\
\hline 7. & PERGURUAN TINGGI & 54 & 3,86 \\
\hline & Jumlah & 1400 & 100 \\
\hline
\end{tabular}

\section{Mata Pencaharian Masyarakat Desa Pinilih}

Mata pencaharian penduduk Desa Pinilih sangat beragam, diantaranya sebagai: Petani pemilik, petani penggarap, penggarap, buruh kebun, pekebun peternak, pedagang, sopir, PNS, TNI/POLRI, pensiunan dan lain-lain. Penduduk menurut jenis mata pencaharian penduduk secara rinci dapat dilihat pada Tabel 4.

Tabel 4. Jenis Mata Pencaharian Masyarakat Desa Pinilih Tahun 2016

\begin{tabular}{llcr}
\hline No & Mata Pencaharian & $\begin{array}{c}\text { Jumlah } \\
\text { penduduk } \\
\text { (Orang) }\end{array}$ & Persentase (\%) \\
\hline 1. & Petani Pemilik & 33 & 2,36 \\
2. & Petani Penggarap & 33 & 2,36 \\
3. & Penggarap & 107 & 7,64 \\
4. & Buruh kebun & 50 & 3,57 \\
5. & Pekebun & 301 & 21,50 \\
6. & Peternak & 6 & 0,43 \\
7. & Pedagang & 29 & 2,07 \\
8. & Sopir & 50 & 3,57 \\
9. & PNS & 18 & 1,29 \\
10 & TNI/POLRI & 2 & 0,14 \\
11 & Pensiunan & 15 & 1,07 \\
12 & Yang tidak/ belum bekerja & 756 & 54,00 \\
\hline \multicolumn{4}{l}{ Sumber : Data Statistik Desa Pinilih, 2016} \\
\end{tabular}

Tabel 4 menunjukkan bahwa jumlah penduduk Desa Pinilih yang telah bekerja yaitu sebanyak 644 orang, dimana jumlah jenis pekerjaan yang mendominasi adalah mata pencaharian sebagai pekebun yang berjumlah 301 orang dengan persentase $46,74 \%$.

\section{Karakteristik Responden}

Jumlah Responden Menurut Kelompok Umur

Umur merupakan salah satu faktor yang dapat mempengaruhi prilaku dalam melakukan atau mengambil keputusan atau kemampuan bekerja secara optimal serta produktif. Seiring dengan perkembangan waktu, umur manusia akan mengalami perubahan dalam hal ini penambahan 
usia yang dapat mengakibatka turunnya tinggkat produktifitas seseorang dalam bekerja (Gusmaniar, 2013). Jumlah respponden menurut umur dapat dilihat pada Tabel 5.

\begin{tabular}{llcr}
\multicolumn{4}{l}{ Tabel 5. Jumlah Responden Menurut Umur } \\
\hline No & Umur Responden & Jumlah (orang) & Persentase (\%) \\
\hline 1. & $21-31$ & 5 & 25,00 \\
2. & $31-40$ & 6 & 30,00 \\
3. & $41-50$ & 3 & 15,00 \\
4. & $>51$ & 6 & 30,00 \\
\hline & Jumlah & $\mathbf{2 0}$ & $\mathbf{1 0 0}$ \\
\hline
\end{tabular}

Tabel 5 menunjukan bahwa jumlah responden berada pada interval umur 31-40 tahun yaitu sebanyak 6 orang $(30,00 \%)$ dan juga interval umur $>51$ tahun 6 orang $(30,00 \%)$, dan responden yang berada pada interval umur 21-30 yaitu sebanyak 5 orang $(25,00 \%)$. Sedangkan umur paling terendah pada interval 41-50 tahun yaitu sebanyak 3 orang $(15,00 \%)$.

\section{Jumlah Responden Menurut Jenis Kelamin}

Jenis kelamin merupakan sesuatu yang membedakan antara laki-laki dan perempuan sesuai dengan kedudukannya. Pekerjaan pada sector non pertanian yang memiliki jenis-jenis pekerjaan tidak hanya dikerjakan oleh tenaga kerja laki-laki saja, melainkan juga dikerjakan oleh tenaga kerja perempuan. Jumlah responden menurut jenis kelamin dapat dilihat pada Tabel 6 .

\begin{tabular}{llcr}
\multicolumn{4}{l}{ Tabel 6. Responden Menurut Jenis Kelamin } \\
\multirow{2}{*}{ No. } & Jenis Kelamin & $\begin{array}{l}\text { Jumlah } \\
\text { (orang) }\end{array}$ & Persentase (\%) \\
\hline 1. & Laki-laki & 10 & 50,00 \\
2. & Perempuan & 10 & 50,00 \\
\hline & Jumlah & $\mathbf{2 0}$ & $\mathbf{1 0 0}$ \\
\hline
\end{tabular}

Sumber: Diolah dari data primer (tahun 2019)

Tabel 6 menunjukkan jenis kelamin responden laki-laki dan perempuan sama dengan persentase $50,00 \%$.

\section{Jumlah Responden Menurut Tingkat Pendidikan}

Pendidikan diperoleh setiap orang dengan dua cara yaitu secara formal dan non-formal. Pendidikan sangat penting dalam usaha peningkatan kualitas sumber daya manusia. Jumlah responden menurut tingkat pendidikan dapat dilihat pada Tabel 7.

\begin{tabular}{llcr}
\multicolumn{5}{l}{ Tabel 7. Jumlah Responden Menurut Tingkat Pendidikan } \\
\hline No. & Tingkat Pendidikan & Jumlah (orang) & Persentase (\%) \\
\hline 1. & SD (tamat) & 4 & 20,00 \\
2. & SMP (tamat) & 7 & 35,00 \\
3. & SMA/SMK (tamat) & 8 & 40,00 \\
4. & S1 & 1 & 5,00 \\
\hline & Jumlah & $\mathbf{2 0}$ & $\mathbf{1 0 0}$ \\
\hline
\end{tabular}




\section{Sambungan Tabel 8. Jenis, Manfaat, dan Cara Menggunakan Tanaman Obat Keluarga}

\begin{tabular}{llll}
\hline $\begin{array}{l}\text { Salam } \\
\text { Syzigium } \\
\text { polyanhum })\end{array}$ & $\begin{array}{l}\text { Diare, kencing } \\
\text { manis dan asam } \\
\text { urat. }\end{array}$ & $\begin{array}{l}\text { Daun salam direbus dengan air 4 gelas hingga tersisa } \\
\text { 3 gelas, diminum 3x sehari (kencing manis). Daun } \\
\text { salam muda dan kulit pohon salam dipotong kecil- } \\
\text { kecil dengan air } 4 \text { gelas direbus sehingga tersisa } \\
\text { 3gelas, airnya diminum sehari 3x. }\end{array}$ \\
$\begin{array}{ll}\text { 7. } \\
\begin{array}{l}\text { Pace/mengkudu } \\
\text { (Morindra } \\
\text { citrifolia) }\end{array}\end{array}$ & $\begin{array}{l}\text { Penurun } \\
\text { hipertensi. }\end{array}$ & $\begin{array}{l}\text { Buah pace yang matang diperas dengan air dan } \\
\text { disaring. Air perasan ditambah madu/ gula jawa/ } \\
\text { sirup untuk diminum 2x sehari sampai hipertensi } \\
\text { menurun. }\end{array}$
\end{tabular}

8. Pynaghong

Asam urat, radang

Daun direbus dengan air 3 gelas hingga mendidih, pembekakan pada kulit. airnya diminum pagi dan sore hari (asam urat). Daun ditumbuk sampai halus dioleskan pada bagian yang mengalami peradangan.

\section{Kumis kucing (Orthosiphon aristatus)}

10. Mahkota dewa (Gymura procumbent)

11. Balacae Merah (Jatropha gossypifolia)

12. Pepaya (Carica papaya)

13. Cocor bebek (Calanchu pinnata)

14. Jambu biji (Psidium guajava)
Untuk melancarkan air seni dan kencing batu.

Melancarkan peredaran darah, antibiotik.

Untuk meredakan pegal-pegal.

Untuk melancarkan buang air besar, malaria dan menurunkan panas tubuh.

Menurunkan panas, penyakit kulit dan luka bakar.

Meningkatkan trombosit dalam darah, menghentikan sakit diare/mencret.
Daun kumis kucing disedu dengan air panas yang mendidih, airnya langsung diminum, diminum pagi dan sore.

Buah yang masih hijau diiris tipis, dijemur sampai kering, kemudian disedu dengan air panas mendidih, dan didinginkan.

Bagian yang digunakan adalah batang dan daun muda, ambil beberapa batang dicampur dengan pinaraci direbus sama-sama dan diminum.

Buah yang masak dimakan secara langsung atau dibuat jus. Daun papaya muda ditumbuk halus ditambah air 1 gelas kemudian disaring, diminum airnya pada pagi hari setelah makan (malaria).

Daun cocor bebek dengan air jeruk nipis ditumbuk, digunakan sebagai kompres bagian ketiak. Daunnya direbus dengan air 3 gelas hingga tersisa 1 gelas, airnya diminum (menurunkan panas). Daun ditumbuk halus kemudian langsung dioleskan pada bagian terluka,

Buah dijus, dapat ditambahkan madu atau gula merah, langsung dikomsumsi. Daun mudanya direbus dengan air 3 gelas hingga tersisa 1 gelas ditambahkan madu, digunakan sebagai minuman (menambah trombasit). Daun jambu muda ditambah garam sedikit lalu ditumbuk halus dan diberi air, saring dan hasil saringan diperas untuk diminum (diare). 
Sambungan Tabel 8. Jenis, Manfaat, dan Cara Menggunakan Tanaman Obat Keluarga

$\begin{array}{lll}\text { 15. } \begin{array}{l}\text { Belimbing buah } \\ \text { (Averhoa } \\ \text { carambola) }\end{array} & \begin{array}{l}\text { menurunkan } \\ \text { hipertensi }\end{array} & \begin{array}{l}\text { buah yang matang, dikomsumsi secara langsung atau } \\ \text { dibuat jus dengan menambahkan madu sedikit. }\end{array} \\ \text { 16. Sirih (Piper betle) } & \begin{array}{l}\text { Mimisan, } \\ \text { keputihan, jantung } \\ \text { berdebar. }\end{array} & \begin{array}{l}\text { Daun sirih, cengkeh, direbus dengan } 4 \text { gelas air } \\ \text { hingga tersisa 1 gelas, diminum pagi dan sore hari. }\end{array} \\ \begin{array}{l}\text { 17. Pare } \\ \text { (Momordica } \\ \text { charantia) }\end{array} & \begin{array}{l}\text { Untuk penyakit } \\ \text { cacingan, kencing } \\ \text { manis, susah }\end{array} & \begin{array}{l}\text { Daun pare direbus dan airnya diminum atau digiling } \\ \text { dicampur air. Buah pare diparut disedu dengan air } \\ \text { panas, airnya diminum (obat kencing manis). }\end{array}\end{array}$
BAB.

18. Saga

(Abrus presatorius)

Obat batuk, sakit

Daun saga dilayukan, selanjutnya dikeringkan kuning.

19. Kokuru merah (Ocimum $s p$ )

Mengobati panas dan batuk.

20. Tali pahit (Tinospora

Obat malaria. crispa)

21. Jeruk nipis Mencairkan dahak dibawah panas matahari ditambah daun sirih dan kencur, direbus dengan air 3 gelas sampai mendidih, airnya diminum (sariawan dan obat batuk).

(Citrus aurantum) pada batuk.

Daun diambil lalu ditumbuk dan diperas airnya.

Ambil getahnya dan batangnya, rebus kemudian diminum.

22. Kembang sepatu ( Hibiscus

Mengobati patah rosasinensis $L$ ) tulang.

Jeruk nipis diperas diambil airnya, ditambahkan sedikit kapur sirih, garam, dan minyak kayu putih, airnya digosokkan dibagian dada. Air jeruk ditambah garam dan madu/ gula merah selanjutnya diminum (pencair dahak)

Bunga diambil dan daun mudanya dicincang halus dan ditempelkan pada bagian yang sakit.

23. Kemukus (Piper cubeba)

Radang selaput lender, saluran kemih dan asma.

Kemukus dipotong kecil-kecil lalu direbus dengan air 2 gelas menjadi 1gelas, didinginkan selanjutnya diminum pagi dan sore hari.

24. Katuk

(Sauropus androggynus)

Melancarkan asi ibu, menurunkan tekanan darah tinggi, mengatur denyut jantung.

25. Lidah buaya Ambeien,rambut (Aloe sp) rontok, sesak nafas. 


\section{Sambungan Tabel 8. Jenis, Manfaat, dan Cara Menggunakan Tanaman Obat Keluarga}

\begin{tabular}{|c|c|c|c|}
\hline 26. & $\begin{array}{l}\text { Alang-alang } \\
\text { (Imperata } \\
\text { cylindrica) }\end{array}$ & $\begin{array}{l}\text { Peradangan ginjal, } \\
\text { infeksi saluran } \\
\text { kemih, mimisan, } \\
\text { hipertensi, } \\
\text { hepatitis, air } \\
\text { kemih berdarah. }\end{array}$ & $\begin{array}{l}\text { akar alang-alang dengan daun kumis kucing, kunyit } \\
\text { dan daun kaki kuda. Semua bahan direbus dengan } 4 \\
\text { gelas air hingga tinggal } 2 \text { gelas, dapat ditambahkan } \\
\text { madu selanjutnya diminum. }\end{array}$ \\
\hline 27. & $\begin{array}{l}\text { Belimbing wuluh } \\
\text { (Averhoa bilimbi) }\end{array}$ & $\begin{array}{l}\text { Sariawan, obat } \\
\text { batuk. }\end{array}$ & $\begin{array}{l}\text { Daun belimbing wuluh, cengkeh, merica dan beras } \\
\text { merah direndam semalam, bahan lain ditumbuk } \\
\text { halus, semua distukan dan digosokkan pada bagian } \\
\text { yang sakit. Buah direbus ditambah madu selanjutnya } \\
\text { diminum. }\end{array}$ \\
\hline 28. & $\begin{array}{l}\text { Kayu manis } \\
\text { (Cinnamomum } \\
\text { burmani) }\end{array}$ & $\begin{array}{l}\text { Anti rematik, } \\
\text { sariawan, } \\
\text { lambung (sakit } \\
\text { perut) }\end{array}$ & $\begin{array}{l}\text { Kulit kayu manis docampur dengan 3air gelas, } \\
\text { direbus sampai mendidih dan tersisa } 1 \text { gelas, } \\
\text { dinginkan dan dapat ditambah madu airnya diminum. }\end{array}$ \\
\hline 29. & $\begin{array}{l}\text { Ubi jalar } \\
\text { (Ipomoea batatas) }\end{array}$ & $\begin{array}{l}\text { Meningkatkan } \\
\text { trombosit pada } \\
\text { penyakit demam } \\
\text { berdarah } \\
\text { menghilangkan } \\
\text { gas dalam perut. }\end{array}$ & $\begin{array}{l}\text { Daun ubi } 10 \text { lembar direbus dengan air } 4 \text { gelas hingga } \\
\text { mendidih, dinginkan dan airnya diminum. Rimpang } \\
\text { ubi dimasak dengan air sampai mendidih dan air } \\
\text { rebusan diminum, rimpang yang direbus dimakan. }\end{array}$ \\
\hline 30. & $\begin{array}{l}\text { Beluntas (Plucea } \\
\text { indica) }\end{array}$ & $\begin{array}{l}\text { Keputihan pada } \\
\text { wanita dan bau } \\
\text { badan/ keringat. }\end{array}$ & $\begin{array}{l}\text { Daun beluntas ditambah kunyit yang dipotong- } \\
\text { potong, diberi air } 4 \text { gelas kemudian direbus sampai } \\
\text { mendidih, tambahkan gula sesuai selera dan air } \\
\text { rebusan diminum. }\end{array}$ \\
\hline
\end{tabular}

Sumber: Diolah dari data primer (tahun 2019).

\section{Pembahasan \\ Pengetahuan Tentang Tanaman Obat}

Berdasarkan penelitian yang diperoleh dari wawancara dengan kelompok masyarakat (lakilaki dan perempuan) menyangkut pengetahuan tentang tanaman obat, maka diketahui bahwa masyarakat di Desa Pinilih ada yang memiliki pengetahuan tentang manfaat tanaman obat namun ada beberapa masyarakat yang kurang mengetahui tentang manfaat tanaman obat tertentu. Misalnya wanita atau pria yang di wawancara ada yang mengetahui bahwa satu tanaman mampu mengobati berbagai atau lebih dari satu penyakit. Seperti tanaman obat jahe tidak hanya mengobati penyakit batuk namun juga mengobati nyeri pada tulang, begitu juga tanaman daun gedi selain bisa mempermudah persalinan bisa juga untuk menambah produksi air susu ibu (ASI), namun ada masyarakat yang mengetahui satu tanaman hanya untuk mengobati satu penyakit saja.
Pengetahuan seseorang terhadap tanaman obat dapat diketahui dengan lamanya pengetahuan yang diperoleh orang tersebut. Pengetahuan responden tentang tanaman obat dapat dilihat pada Tabel 9.

Tabel 9. Pengetahuan Tentang Tanaman Obat

\begin{tabular}{lcr}
\hline \multicolumn{1}{c}{ Tahun } & Jumlah (Responden) & Persentase (\%) \\
\hline$\leq 20$ & 9 & 45 \\
$21-40$ & 6 & 30 \\
$>40$ & 5 & 25 \\
\hline Jumlah & $\mathbf{2 0}$ & $\mathbf{1 0 0}$ \\
\hline Sumber:
\end{tabular}

Sumber: Diolah dari data primer (Tahun 2019)

Tabel 9 menunjukkan bahwa, 9 responden dengan persentase $45 \%$ memiliki pengetahuan tentang tanaman obat $\leq 20$ tahun, 6 responden dengan persentase $30 \%$ memiliki pengetahuan tanaman obat berkisar antara $21-40$ tahun, sedangkan 5 responden dengan persentase $25 \%$ memiliki pengetahuan tanaman obat $>40$ tahun. 
Menurut hasil wawancara dengan responden diketahui bahwa, pengetahuan penggunaan tanaman obat ada yang diwariskan oleh orang tua, bisa dikatakan bahwa penggunaan ini dilakukan turun temurun. Dikarenakan disaat masih kecil atau masih remaja, tanaman sudah digunakan dan diperkenalkan.

\section{Penerapan Tanaman Obat dalam Keluarga}

Tanaman obat yang telah diketahui manfaatnya oleh masyarakat di Desa Pinilih, digunakan untuk bahan racikan pengobatan. Berdasarkan penelitian yang dilakukan tentang tanaman obat, 26 jenis tanaman obat telah diterapakan baik digunakan sendiri ataupun dalam keluarga, dan 4 jenis tanaman obat belum diterapakan. Tanaman - tanaman obat yang diterapkan antara lain : temu lawak, kencur, jahe, lengkuas, salam, Pynahong, kumis kucing, mahkota dewa, balacae merah, cocor bebek, jambu biji, sirih, pare, saga, kokuru merah, tali pahit, jeruk nipis, kemukus, katuk, lidah buaya, alang alang, belimbing wuluh, kayu manis, beluntas. Sedangkan 4 jenis tanaman obat yang hanya deketahui manfaat nya namun belum diterakan antara lain: pace, kembang sepatu, papaya, ubi jalar. Penggunaan tanaman obat di mulai dari cara meracik dan menggunakanya, seperti yang dikatakan oleh responden misalnya, Temulawak untuk menurunkan tekanan darah dan melancarkan pencernaan, cara menerapkanya diparut atau ditumbuk halus kemudian ditambah air matang lalu diperas dan airnya diminum. Namun masih ada juga masyarakat di Desa Pinilih, yang memilih untuk menggunakan obat Generik sebagai cara mudah untuk pengobatan didasarkan karena proses dalam pembuatan atau meracik tanaman obat memakan waktu.

\section{Tempat Budidaya Tanaman Obat}

Desa Pinilih merupakan desa dengan tumbuhan obat paling banyak didapatkan dengan ditanam dan dipelihara di pekarangan ataupun kebun. Menurut responden di desa Pinilih, mereka sengaja menanami berbagai jenis macam tanaman obat di pekarangan dan kebun untuk menjaga kesehatan dan mendapatkan kesembuhan dari untuk berbagai penyakit. Tempat tumbuh setiap tanaman obat dapat dilihat pad Tabel 10.
Tabel 10. Tempat Budidaya Tanaman Obat

\begin{tabular}{|c|c|c|c|}
\hline No & Tempat Tumbuh & $\begin{array}{c}\text { Jumlah } \\
\text { Responden }\end{array}$ & Persentase (\%) \\
\hline 1 & Pekarangan & 15 & 75 \\
\hline 2 & Kebun & 5 & 25 \\
\hline & Jumlah & 20 & 100 \\
\hline
\end{tabular}

Tabel 10 menunjukkan bahwa masyarakat (responden) kebanyakan memanfaatkan pekarangan rumah sebagai wadah untuk budidaya tanaman obat yaitu sebanyak 15 orang dengan persentase 75 persen dan sedangkan untuk budidaya tanaman obat di kebun hanya 5 orang dengan persentase 25 persen. Sementara itu tumbuhan liar yang dianggap memiliki fungsi sebagai obat dibiarkan tumbuh di kebun sehingga sebagian besar tumbuhan obat dapat diperoleh dari lokasi ini.

Selain itu, penggunaan tanaman obat di Desa Pinilih digunakan hampir semua kalangan umur mulai dari yang balita atau anak-anak, orang dewasa ibu melahirkan, dan lansia. Obat tradisional atau tanaman obat yang sudah sering digunakan sebagian besar ada yang diwariskan pengetahuannya dari orangtua terdahulu, dimulai dari kegunaan tanaman obat sampai cara penerapannya.

\section{KESIMPULAN DAN SARAN}

\section{Kesimpulan}

Berdasarkan hasil penelitian dan pembahasan dapat ditarik beberapa kesimpulan sebagai berikut :

1. Dari penelitian yang dilakukan di Desa Pinilih, diketahui bahwa setiap responden mengetahui manfaat jenis-jenis tanaman obat yang telah digunakan atau diterapkan, maupun jenis tanaman obat yang hanya diketahui kegunaannya. Ada 30 jenis tanaman obat baik yang diketahui maupun diterapkan oleh responden Di desa Pinilih.

2. Pengetahuan dan Penerapan tentang tanaman obat inipun sudah diketahui dan digunakan sudah sejak lama, dimana responden menjawab pengetahuan dan penerapan ini diwariskan oleh orang tua sebelumnya, sehingga penggunaan tanaman obat ini masih dilakukan sampai sekarang. 
3. Untuk mendapatkan tanaman obat juga tidak terlalu sulit, karena tanaman obat ditanam atau dibudidayakan ada yang di pekaranagan, ada juga yang tumbuh dan ditanam di kebun.

\section{Saran}

1. Perlu upaya untuk melestarikan pengetahuan tentang tanaman obat ini pada generasi muda sebagai budaya pengobatan leluhur, serta sebagai upaya kemandirian masyarakat dalam pengembangan pengetahuan penggunaan tanaman obat dalam menjaga kesehatan.

2. Perlu dilakukan penyuluhan berkelanjutan tentang manfaat, cara penerapan tanaman obat sebagai obat tradisional di Desa Pinilih Kecamatan Dimembe.

\section{DAFTAR PUSTAKA}

Dewoto, H. R. 2007. Pengembangan obat tradisional Indonesia menjadi fitofarmaka. Majalah kedokteran Indonesia, 57 (7), 205-211.

Nurhidayat, O. 2012. Perbandingan Media Power Point Dengan Flip Chart Dalam Meningkatkan Pengetahuan Kesehatan Gigi Dan Mulut. Unnes Journal Of Public Health, $1(1)$.

Riyanto, A. 2016. Pendidikan Kesehatan Dengan Metode Ceramah Untuk Meningkatkan Pengetahuan Keluarga Dengan Gastritis (Doctoral dissertation, Universitas Muhammadiyah Surakarta).

Sari, L. O. R. K. 2012. Pemanfaatan obat tradisional dengan pertimbangan manfaat dan keamanannya. Pharmaceutical Sciences and Research (PSR), 3(1).

Zein, U. 2005. Pemanfaatan tumbuhan obat dalam upaya pemeliharaan kesehatan. Medan: Universitas Sumatera Utara. 